\title{
Rolling in the Dough: The Continued Surge in Individual Contributions to Presidential Candidates and Party Committees
}

David B. Magleby

david_magleby@byu.edu

Follow this and additional works at: https://scholarsarchive.byu.edu/facpub

Part of the Economics Commons

\section{Original Publication Citation}

Magleby, David B. (28) "Rolling in the Dough: The Continued Surge in Individual Contributions to Presidential Candidates and Party Committees," The Forum: Vol. 6 : Iss. 1, Article 5.

\section{BYU ScholarsArchive Citation}

Magleby, David B., "Rolling in the Dough: The Continued Surge in Individual Contributions to Presidential Candidates and Party Committees" (2008). Faculty Publications. 198.

https://scholarsarchive.byu.edu/facpub/198 


\title{
The Forum
}

Volume 6, Issue 1 2008

Article 5

Has the U.S. Campaign Finance System Collapsed?

\section{Rolling in the Dough: The Continued Surge in Individual Contributions to Presidential Candidates and Party Committees}

\author{
David B. Magleby*
}

*Brigham Young University - Utah, david_magleby@ byu.edu

Copyright (c) 2008 The Berkeley Electronic Press. All rights reserved. 


\title{
Rolling in the Dough: The Continued Surge in Individual Contributions to Presidential Candidates and Party Committees*
}

\author{
David B. Magleby
}

\begin{abstract}
The dramatic growth in the numbers of individuals contributing to presidential candidates and the surge in total amounts being contributed has generated substantial media attention in the 2008 presidential election. Individuals are giving more, in part, because the 2002 Bipartisan Campaign Reform Act (BCRA) raised contribution limits and encouraged "max-out" donors to contribute to party committees as well. This study compares individual contributions to presidential candidates and party committees in 1999, the year prior to the last pre-BCRA presidential election, and in the years prior to post-BCRA presidential elections.
\end{abstract}

KEYWORDS: BCRA, fundraising, individual contributions, party contributions, candidate contributions

*David B. Magleby is Distinguished Professor of Political Science and Dean of the College of Family, Home, and Social Sciences at Brigham Young University. He has published books and articles on direct democracy, campaign finance, and voting behavior. I am grateful for the assistance of Tim Taylor, Stephanie Curtis, Bradley Jones, Aaron Anderson, and Lindsay Nielson, who are a superb team of research assistants. Hilary Hendricks provided helpful editorial assistance. I am also grateful for the support of the Center for the Study of Elections and Democracy. Much of this research is drawn from work previously funded by the Pew Charitable Trusts, Joyce Foundation, Carnegie Corporation of New York, and JEHT Foundation. 
During the debate over passage of the Bipartisan Campaign Reform Act (BCRA) in 2002, and in the litigation which followed, there was widespread speculation about the impact of forcing presidential candidates and national party committees to rely on limited contributions from individual donors. In previous elections, unlimited "soft money" donations to parties, allowed under the Federal Election Campaign Act (FECA as amended in 1974) only for the support of general party activities, had been used to benefit specific candidates. When BCRA banned all soft money donations to parties, politicians and analysts alike worried that the end of soft money would seriously hamper electioneering. Instead, a growing number of individual donors, particularly small donors, are bolstering the election process as never before. This paper discusses how candidates and parties have adapted to BCRA, as shown in donation receipts from election cycles before and after the legislation took effect.

Early predictions about BCRA's impact ranged from dismal to bright. Political scientist Sidney Milkis warned, "BCRA threatens the reinvigoration of national parties and the revitalization of America's federal democracy" (2003, 43). Another commentator described BCRA as a "suicide bill for the Democrats" (Gitell 2003, 106). But not all commentators on BCRA were pessimists about the ability of presidential candidates and party committees to function in a world without soft money. As Jonathan Krasno and Frank Sorauf argued, "Certainly, BCRA's implementation will decrease the amount of money available to state and local party organizations in the short turn, but that loss will stimulate them to broaden their base of contributors and raise more hard money. Belt tightening will also force them to use their money more efficiently and effectively" $(2003,57)$.

In practice, the parties have adapted well to BCRA. National party committees made a final push in 2002 to acquire as much soft money as possible, which leaves as no surprise that the Senate and House party committees raised less in 2004 than in 2002 (Magleby and Monson 2004, 274-276; Kolodny and Dwyre 2006, 184). However, the Republican National Committee and the Democratic National Committee raised more hard money alone in 2004 than they had in both soft and hard money contributions combined in 2002 (Kolodny and Dwyre, 183184).

BCRA doubled what individuals could contribute to candidates from $\$ 2,000$ per election cycle $(\$ 1,000$ in the nomination phase and $\$ 1,000$ in the general election) to $\$ 4,000$ in 2004 , again evenly divided between the nomination and general election phases. BCRA also indexed these limits for inflation, such that in 2008 the maximum an individual can give a candidate during the cycle is $\$ 4,600$. BCRA also increased the aggregate limit for an individual giving to candidates, party committees, and political action committees (PACs) in a two-year election cycle from $\$ 25,000$ to $\$ 95,000$. Indexed for inflation, the combined donation limit in 2008 is $\$ 108,200$. Of this amount only $\$ 42,700$ can go to candidates, leaving 
$\$ 65,500$ to be divided among PACs and national, state, and local parties. Of those funds, a maximum of $\$ 10,000$ may be given to any one state or local party committee, a maximum of $\$ 28,500$ to any one national party committee, and a maximum of $\$ 5,000$ to any one PAC, with total PAC donations not exceeding $\$ 40,000$ (Center for Responsive Politics 2007).

By building in a fraction of the aggregate limit that could only go to political parties, the BCRA reformers created an incentive for donors to include party committees in their election cycle contribution allocations. What has been the actual experience of presidential candidates and party committees in raising money from individual donors under these new BCRA contribution limits?

The scope of this study is to compare individual contributions to presidential candidates and party committees in the year prior to the 2000, 2004 and 2008 presidential elections. This limited scope is necessitated by the timing of this publication. But there is widespread agreement in the literature on the importance of fundraising in what some have called the "money primary" that occurs in the years prior to the year of the presidential caucuses, primaries, and general election (Goff 2004). Since most candidates who do poorly in early states, particularly Iowa and New Hampshire, quickly withdraw, the importance of raising and spending money in those early states cannot be overemphasized. This is especially true as the momentum generated from early wins spurs additional funds and media attention to sustain a campaign, while early losses can cause a campaign to dry up rapidly (Magleby and Mayer 2008, 147-149). This has been especially true in 2008, in which early losses eroded the comfortable national polling leads of Hillary Clinton and Rudy Giuliani.

\section{Individual Donors to Presidential Candidates: 1997-99, 2001-03, AND 2005-07}

Table 1 provides the total amounts raised by candidates through the year prior to the election year for the 2000, 2004 and 2008 presidential elections. The 2000 presidential election was the last held under the contribution limits of the Federal Election Campaign Act (FECA). Individuals could contribute a maximum of $\$ 2,000$ to a candidate in the cycle (primary and general election), had an aggregate cycle hard money limit of $\$ 25,000$ per year to candidates and party committees, and could give unlimited amounts to the party committees. Under FECA, candidates participating in the partial public financing of the nomination phase could expect that contributions from individuals of up to $\$ 250$ would be matched. 
Table 1

Candidate Receipts from Individuals by Quarter in the Year Before the Election

\begin{tabular}{|c|c|c|c|c|c|c|}
\hline Candidate & $\begin{array}{c}\text { Prior to } \\
\text { Quarter 1 } \\
\end{array}$ & Quarter 1 & Quarter 2 & Quarter 3 & Quarter 4 & $\begin{array}{l}\text { Total as of } \\
\text { Quarter } 4\end{array}$ \\
\hline \multicolumn{7}{|l|}{ 1997-99 } \\
\hline \multicolumn{7}{|l|}{ Democrats } \\
\hline Bradley & $\$ 88,983$ & $\$ 4,275,688$ & $\$ 7,338,870$ & $\$ 7,254,590$ & $\$ 8,265,266$ & $\$ 27,223,397$ \\
\hline Gore & $\$ 0$ & $\$ 8,881,976$ & $\$ 8,573,060$ & $\$ 6,635,923$ & $\$ 3,752,902$ & $\$ 27,843,861$ \\
\hline All Dems & $\$ 88,983$ & $\$ 13,319,685$ & $\$ 16,551,427$ & $\$ 14,489,671$ & $\$ 12,666,785$ & $\$ 57,116,551$ \\
\hline \multicolumn{7}{|l|}{ Republicans } \\
\hline Bush & $\$ 0$ & $\$ 7,474,082$ & $\$ 28,666,461$ & $\$ 19,520,775$ & $\$ 9,729,605$ & $\$ 65,390,923$ \\
\hline Forbes & $\$ 0$ & $\$ 16,538$ & $\$ 2,695,741$ & $\$ 1,518,056$ & $\$ 1,017,271$ & $\$ 5,247,606$ \\
\hline McCain & $\$ 0$ & $\$ 1,678,335$ & $\$ 2,405,672$ & $\$ 2,943,546$ & $\$ 6,177,784$ & $\$ 13,205,337$ \\
\hline All Reps & $\$ 0$ & $\$ 14,112,330$ & $\$ 44,349,465$ & $\$ 29,999,712$ & $\$ 20,461,236$ & $\$ 108,922,743$ \\
\hline \multicolumn{7}{|l|}{ 2001-03 } \\
\hline \multicolumn{7}{|l|}{ Democrats } \\
\hline Clark & $\$ 0$ & $\$ 0$ & $\$ 0$ & $\$ 3,484,109$ & $\$ 10,177,447$ & $\$ 13,661,556$ \\
\hline Dean & $\$ 201,960$ & $\$ 2,731,302$ & $\$ 7,574,917$ & $\$ 14,762,373$ & $\$ 15,650,903$ & $\$ 40,921,455$ \\
\hline Edwards & $\$ 0$ & $\$ 7,403,936$ & $\$ 4,465,110$ & $\$ 2,071,961$ & $\$ 1,745,640$ & $\$ 15,686,646$ \\
\hline Kerry & $\$ 495,398$ & $\$ 6,956,448$ & $\$ 5,832,429$ & $\$ 3,873,040$ & $\$ 2,248,683$ & $\$ 19,405,997$ \\
\hline All Dems & $\$ 3,623,774$ & $\$ 25,672,433$ & $\$ 30,954,508$ & $\$ 31,297,815$ & $\$ 37,346,483$ & $\$ 128,895,013$ \\
\hline \multicolumn{7}{|l|}{ Republicans } \\
\hline Bush & $\$ 0$ & $\$ 0$ & $\$ 33,681,050$ & $\$ 48,717,340$ & $\$ 46,385,885$ & $\$ 128,784,275$ \\
\hline All Reps & $\$ 0$ & $\$ 0$ & $\$ 33,681,050$ & $\$ 48,717,340$ & $\$ 46,385,885$ & $\$ 128,784,275$ \\
\hline \multicolumn{7}{|l|}{ 2005-07 } \\
\hline \multicolumn{7}{|l|}{ Democrats } \\
\hline Clinton & $\$ 0$ & $\$ 25,805,109$ & $\$ 26,709,804$ & $\$ 27,017,911$ & $\$ 26,538,792$ & $\$ 106,071,617$ \\
\hline Edwards & $\$ 0$ & $\$ 14,021,284$ & $\$ 9,036,908$ & $\$ 7,092,914$ & $\$ 4,834,761$ & $\$ 34,985,868$ \\
\hline Obama & $\$ 0$ & $\$ 25,665,688$ & $\$ 32,921,935$ & $\$ 20,650,853$ & $\$ 22,846,503$ & $\$ 102,084,979$ \\
\hline All Dems & $\$ 37,230$ & $\$ 77,867,543$ & $\$ 63,151,311$ & $\$ 54,846,650$ & $\$ 58,240,118$ & $\$ 254,142,852$ \\
\hline \multicolumn{7}{|l|}{ Republicans } \\
\hline Giuliani & $\$ 114,312$ & $\$ 15,822,025$ & $\$ 17,391,048$ & $\$ 11,430,278$ & $\$ 14,031,552$ & $\$ 58,789,214$ \\
\hline Huckabee & $\$ 0$ & $\$ 526,957$ & $\$ 748,399$ & $\$ 1,029,062$ & $\$ 6,625,134$ & $\$ 8,929,552$ \\
\hline McCain & $\$ 650,386$ & $\$ 12,701,057$ & $\$ 11,187,073$ & $\$ 5,641,745$ & $\$ 6,781,807$ & $\$ 36,962,068$ \\
\hline Paul & $\$ 0$ & $\$ 638,389$ & $\$ 2,364,428$ & $\$ 5,226,602$ & $\$ 19,917,241$ & $\$ 28,146,661$ \\
\hline Romney & $\$ 0$ & $\$ 20,596,399$ & $\$ 14,161,040$ & $\$ 9,727,578$ & $\$ 9,027,461$ & $\$ 53,512,478$ \\
\hline All Reps & $\$ 774,637$ & $\$ 53,650,097$ & $\$ 42,368,438$ & $\$ 45,851,118$ & $\$ 64,678,763$ & $\$ 207,323,053$ \\
\hline
\end{tabular}

George W. Bush in his 2000 race was the first non-self-financed candidate seeking a major party nomination to not participate in the FECA presidential nomination matching fund provision for the caucuses and primaries. All other announced candidates in 2000 accepted matching funds except for the largely self-financed Steve Forbes. In the 1997-99 period, Bush built a now legendary fundraising operation with individual donors, many of whom gave the maximum allowable. His approach relied heavily on personal contacts and a system of hierarchal contributors called the "Pioneers," a group of 226 business executives, 
political leaders, lawyers, and lobbyists, who raised $\$ 100,000$ or more each in $\$ 1,000$ increments. They raised about one fourth of Bush's total funds (Green and Bigelow 2002, 59).

In the 2001-03 period, former Vermont governor Howard Dean, who raised less than half as much as John Edwards or John Kerry in the first quarter of 2003, saw his contributions outpace his opponents' thereafter and ended up with more than twice as much money raised from individuals as any of the Democratic candidates.

George W. Bush's reelection campaign by year's end 2003 matched in receipts those of all of his Democratic opponents combined. Bush enlarged his hierarchical contributor program, adding "Rangers" (fundraisers who raised at least \$200,000) and "Super Rangers" (Rangers who raised an additional \$300,000 for the Republican National Committee), to his $\$ 100,000$-level Pioneers. Bush again relied on large individual donors, with 61 percent of his primary season receipts coming from maximum-donation, or "max-out," donors; though maximum-level donations made up just 17 percent of his receipts in the "bridge" period between primary season and the general election contest (Green 2006, 103).

Bush's general election opponents in 2000 and 2004 also had similar fundraising structures, with status ascribed to the aggregate amounts raised. Al Gore had his "Board of Directors"; John Kerry, "Trustees," "Vice Chairs," and "Co-Chairs." The primary stage of the 2004 cycle was essentially a large-donor game.

Contributions from individuals increased dramatically in 2007 as compared to 1999 and 2003. Three candidates raised more in the first quarter of 2007 than was raised by any candidate in a first quarter in a prior year. Hillary Clinton, Barack Obama, and Mitt Romney all raised in excess of \$20 million from individuals in the first quarter, and while Romney's receipts from individuals dipped in the second and subsequent quarters, Clinton and Obama raised more money from individuals in the second quarter than they had in the first. A surprise to many was the late surge in individual contributions to Texas Republican Congressman Ron Paul, who raised \$19.9 million in the fourth quarter of 2007-the second-most successful quarter by any Republican in 2007. (Mitt Romney had raised \$20.6 million in the first quarter of 2007.) Cumulative receipts for Obama and Clinton exceeded $\$ 100$ million by the end of 2007. By standards of prior cycles in fundraising from individuals, Giuliani ( $\$ 58.8$ million), Romney ( $\$ 53.5$ million), McCain (\$37 million), Edwards (\$35 million), and Paul (\$28.1 million) all raised more in the year before the presidential election than any candidate in either party had in the two prior elections except for Bush in 1999 and Dean in 2003. 


\section{SMALLER INDIVIDUAL CONTRIBUTIONS AND THE INCREASING ROLE OF THE INTERNET}

The John McCain campaign in 1999 and 2000 made some early use of the Internet as a mode of raising money, pulling in a modest but pioneering $\$ 5$ million to \$6 million online (Green and Bigelow, 63). In 2003, having seen the impact the Internet was having for interest groups like MoveOn.Org and others, the Howard Dean campaign made online donations a primary source of funds. About half of Dean's \$51 million raised came over the Internet, with over one million unique donors - a remarkable number of participants, just reached and touted this cycle by Barack Obama. Dean's campaign manager, Joe Trippi, characterized Internet fundraising as "the opening salvo in a revolution" (Patterson 2006, 81).

An important development in 2008, and one deserving of further study, is the expanded use of the Internet in contributions. Media stories indicate that candidates' use of the Internet for soliciting contributions has been more effective for all the major 2008 candidates than for those in 2004, but Internet-derived contributions appear most important in the financing of Obama, Edwards, and Paul (Davies 2008).

While individuals can make contributions at any level up to the legal maximum via the Internet, this method appears to be more frequently used by donors making contributions under $\$ 200$. A $\$ 200$ threshold is also used by the Federal Election Commission to track what are called "unitemized contributions." Table 2 presents the amounts raised by each candidate in unitemized contributions, as well as the proportion of their total receipts raised in this manner through 2007.

The Democrats, and especially Obama, had remarkable success through 2007 in raising money in amounts of under $\$ 200$ from individuals. Obama raised more from small individual contributions in 2007 than Bill Bradley, Gore, Edwards, or Kerry had raised from individuals contributing at any level at the same point in the 2000 and 2004 cycles. This is a fair comparison because these small unitemized contributions were not directly impacted by BCRA. Candidates are not required to specify their methods for raising money, but the Obama campaign has released its numbers for January 2008: \$36 million in total, with \$28 million of that coming online (Luo 2008). Republican Ron Paul also saw remarkable success relative to all other candidates except Obama in his fundraising from individuals giving $\$ 200$ or less to candidates. Through 2007, Paul raised over $\$ 17$ million in unitemized contributions, which accounted for 61 percent of all the money he raised through 2007. 
Table 2

Individual Donors' Unitemized Contributions to 2008 Presidential Candidates, with Proportion of These Donations in Candidate's Total Receipts, through 2007

\begin{tabular}{|lrc|}
\hline Candidate & $\begin{array}{c}\text { Donations of } \\
\$ 200 \text { or Less }\end{array}$ & $\begin{array}{c}\text { Unitemized } \\
\text { as \% of Total }\end{array}$ \\
\hline Clinton & $\$ 11,370,741$ & $14 \%$ \\
\hline Obama & $\$ 31,099,525$ & $32 \%$ \\
\hline Edwards & $\$ 11,372,287$ & $36 \%$ \\
\hline Romney & $\$ 6,424,464$ & $12 \%$ \\
\hline Giuliani & $\$ 4,058,720$ & $8 \%$ \\
\hline McCain & $\$ 8,465,225$ & $25 \%$ \\
\hline Paul & $\$ 17,140,999$ & $61 \%$ \\
\hline Huckabee & $\$ 3,159,803$ & $35 \%$ \\
\hline
\end{tabular}

Source: Campaign Finance Institute, "Presidential Fundraising in 2007 Doubles 2003," press release, February 11, 2008. At $<$ http://www.cfinst.org/pr/prRelease.aspx?ReleaseID=179>, accessed March 10, 2008.

The Internet has afforded candidates new tactics in the race for funds. Social networking sites like Facebook.com and MySpace.com allow candidates to connect with and organize more voters, especially young voters; more importantly, these sites provide free, simple, and effective tools that allow supporters to organize themselves. Independent sites like UltiMitt.org and ActBlue.com have brought money and volunteers to the candidates. Additionally, media posting sites like YouTube.com and Flickr.com give opposition researchers and imaginative supporters a platform to pillory or praise candidates. For example, as of this printing, hip-hop artist will.i.am's Obama-supporting music video "Yes We Can," has received over 12 million views on YouTube.com alone. But the Internet's greatest strength may be how it allows nearly instantaneous communication with supporters. For instance, when conservative pundit Ann Coulter criticized John Edwards in a speech, his campaign immediately posted the offensive video prominently on its website and sent out an email appealing for $\$ 100,000$ in "Coulter Cash." The campaign raised $\$ 300,000$ from the incident (Frontrunner 2007).

Recent press reports, some not confirmed by candidates, indicate that the surge in individual contributions to McCain, Clinton, and Obama has continued into 2008. During January, Obama is reported to have raised \$36 million compared to Clinton's near \$14 million and McCain's \$12 million (Luo and Zelleny 2008). In February, Clinton raised another $\$ 35$ million, but Obama topped 
that with an estimated $\$ 50$ million (Luo and Zelleny). The Obama February total exceeded the prior record for individual contributions to a candidate in any month - a record previously held by Kerry, who raised \$44 million in March 2004. However, by March 2004 Kerry had already secured the nomination, something Obama had not done in February 2007 (Luo and Zelleny). The Clinton campaign reported that $\$ 30$ million of its $\$ 35$ million raised in February, or more than 85 percent, "had come in over the Internet or in other small donations."

Individuals wanting to give the maximum allowable could give $\$ 2,300$ for the nomination phase of the 2008 election. Table 3 provides the amount raised by each candidate from individuals giving $\$ 2,300$, as well as the proportion of the candidate's total receipts raised from these max-out donations through 2007.

Table 3

Total of Individual Contributions At the Maximum Allowable, with Proportion of These Donations in Candidate's Total Receipts, through 2007

\begin{tabular}{|lcc|}
\hline Candidate & $\begin{array}{c}\text { Donations of } \\
\$ 2300\end{array}$ & $\begin{array}{c}\text { Maximum } \\
\text { Donations as } \\
\text { \% of Total }\end{array}$ \\
\hline Clinton & $\$ 42,291,540$ & $50 \%$ \\
\hline Obama & $\$ 32,024,536$ & $33 \%$ \\
\hline Edwards & $\$ 7,292,010$ & $23 \%$ \\
\hline Romney & $\$ 22,920,441$ & $44 \%$ \\
\hline Giuliani & $\$ 27,854,488$ & $53 \%$ \\
\hline McCain & $\$ 11,936,412$ & $35 \%$ \\
\hline Paul & $\$ 2,157,695$ & $8 \%$ \\
\hline Huckabee & $\$ 2,512,434$ & $28 \%$ \\
\hline
\end{tabular}

Source: Campaign Finance Institute, "Presidential Fundraising in 2007 Doubles 2003," press release, February 11, 2008. At $<$ http://www.cfinst.org/pr/prRelease.aspx?ReleaseID=179>, accessed March 10, 2008.

Hillary Clinton's campaign through 2007 relied much more heavily on individuals contributing the maximum allowable. Half of the money she raised from individuals in this period came from max-out donors. Rudy Giuliani was the only candidate in this period to raise a higher proportion of his money from this type of donor, raising an impressive \$27.9 million from these donors alone. While Obama far outdistanced all other candidates in money raised from donors contributing under $\$ 200$, he raised slightly more money from donors at or near the maximum allowable ( $\$ 32$ million) than from donors making contributions under $\$ 200$ (\$31.1 million). In short, Obama drew substantially from donors at all levels, unlike Paul, who drew heavily from donors making smaller contributions, or Clinton or Guiliani, who relied heavily on max-out contributors. 
While small contributions have increased tremendously in this election cycle, they make up only a slightly larger part of the fundraising pie for most candidates. Large donations have also increased, led again by large-donor hierarchies. In late 2007, Public Citizen and the Campaign Finance Institute estimated that bundlers, such as members of Hillary Clinton's "Hillraisers" and Obama's "National Finance Committee," had raised about 40 percent of these candidates' money (Weissman and Lincoln 2007, 2). Since so much of the funding in 2008 has come online and through small donations, it is likely that bundlers' relative contribution (and, some would argue, relevance) has decreased in recent months (Horowitz 2008).

\section{Individual Contributions to Party Committees}

Over the same three presidential election cycles, have there been similar changes in the patterns of individual contributions to political party committees? BCRA's incentive for individuals wishing to contribute the maximum allowable to give to the party committees seems to be aiding fundraising after all. Table 4 provides the receipts for each of the six national party committees: the Democratic National Committee (DNC), the Republican National Committee (RNC), the National Republican Senatorial Committee (NRSC), the Democratic Senatorial Campaign Committee (DSCC), the Democratic Congressional Campaign Committee (DCCC) and the National Republican Congressional Committee (NRCC).

Table 4

Cumulative Individual Contributions to Party Committees, 1999, 2003, 2007

\begin{tabular}{|lrrrrrr|}
\hline $\mathbf{1 9 9 9}$ & DNC & \multicolumn{1}{c}{ DSCC } & \multicolumn{1}{c}{ DCCC } & \multicolumn{1}{c|}{ RNC } & \multicolumn{1}{c|}{ NRSC } & \multicolumn{1}{c|}{ NRCC } \\
\hline Jan & no report & $\$ 402,705$ & $\$ 383,597$ & $\$ 4,377,841$ & $\$ 1,221,135$ & no report \\
\hline Feb & no report & $1,315,039$ & 996,500 & $8,293,508$ & $2,714,773$ & no report \\
\hline Mar & no report & $2,018,211$ & $2,099,043$ & $12,075,510$ & $3,951,438$ & no report \\
\hline Apr & no report & $2,563,879$ & $2,913,639$ & $15,538,322$ & $4,799,039$ & no report \\
\hline May & no report & $3,484,821$ & $3,621,852$ & $18,431,846$ & $5,658,490$ & no report \\
\hline June & $13,795,384$ & $4,203,525$ & $4,645,676$ & $21,940,913$ & $6,714,759$ & $12,601,048$ \\
\hline July & no report & $4,954,501$ & no report & $25,384,544$ & $7,733,205$ & no report \\
\hline Aug & no report & $5,504,981$ & no report & $28,561,093$ & $9,066,036$ & no report \\
\hline Sep & no report & $5,978,022$ & no report & $31,643,643$ & $10,198,397$ & no report \\
\hline Oct & no report & $6,516,239$ & no report & $34,189,070$ & $11,288,551$ & no report \\
\hline Nov & no report & $7,082,985$ & no report & $37,000,968$ & $12,330,290$ & no report \\
\hline Dec & $24,334,318$ & $7,930,492$ & $9,772,564 *$ & $41,888,677$ & $13,626,413$ & $25,580,066$ \\
\hline
\end{tabular}




\begin{tabular}{|lrrrrrr|}
\hline 2003 & \multicolumn{1}{c}{ DNC } & \multicolumn{1}{c}{ DSCC } & \multicolumn{1}{l}{ DCCC } & \multicolumn{1}{c}{ RNC } & \multicolumn{1}{c|}{ NRSC } & \multicolumn{1}{c|}{ NRCC } \\
\hline Jan & $\$ 2,089,979$ & $\$ 413,562$ & $\$ 492,333$ & $\$ 11,390,893$ & $\$ 1,083,772$ & $\$ 5,817,767$ \\
\hline Feb & $4,623,773$ & $1,067,312$ & $1,221,234$ & $20,909,106$ & $2,786,656$ & $13,558,101$ \\
\hline Mar & $7,855,876$ & $3,258,717$ & $3,483,814$ & $29,214,587$ & $4,760,530$ & $20,163,119$ \\
\hline Apr & $10,162,326$ & $4,185,385$ & $4,549,765$ & $36,780,201$ & $7,480,930$ & $28,018,358$ \\
\hline May & $12,702,115$ & $5,136,098$ & $5,837,995$ & $46,409,983$ & $10,147,392$ & $35,072,264$ \\
\hline June & $17,397,134$ & $7,791,394$ & $8,158,596$ & $54,494,171$ & $12,158,764$ & $40,893,945$ \\
\hline July & $20,459,167$ & $9,135,477$ & $9,417,966$ & $62,263,825$ & $13,823,158$ & $46,268,694$ \\
\hline Aug & $24,575,638$ & $10,378,797$ & $10,706,827$ & $68,240,967$ & $15,621,021$ & $49,999,513$ \\
\hline Sep & $29,440,455$ & $12,745,160$ & $12,489,133$ & $76,417,225$ & $17,703,501$ & $54,280,307$ \\
\hline Oct & $34,020,881$ & $13,434,378$ & $14,149,646$ & $83,901,088$ & $19,326,628$ & $58,270,377$ \\
\hline Nov & $36,973,673$ & $14,852,174$ & $15,835,294$ & $88,557,820$ & $20,718,552$ & $61,149,317$ \\
\hline Dec & $41,603,527$ & $17,421,597$ & $18,907,904$ & $105,159,694$ & $22,207,607$ & $65,560,862$ \\
\hline
\end{tabular}

\begin{tabular}{|lrrrrrr|}
\hline 2007 & \multicolumn{1}{c}{ DNC } & \multicolumn{1}{c}{ DSCC } & \multicolumn{1}{c}{ DCCC } & \multicolumn{1}{c|}{ RNC } & \multicolumn{1}{c|}{ NRSC } & \multicolumn{1}{c|}{ NRCC } \\
\hline Jan & $\$ 5,151,167$ & $\$ 1,205,440$ & $\$ 1,175,282$ & $\$ 10,353,011$ & $\$ 631,921$ & $\$ 2,466,549$ \\
\hline Feb & $9,381,254$ & $3,110,771$ & $4,725,943$ & $17,091,412$ & $2,120,975$ & $5,287,917$ \\
\hline Mar & $14,517,932$ & $10,209,333$ & $12,059,929$ & $24,285,182$ & $4,369,081$ & $10,104,947$ \\
\hline Apr & $18,374,880$ & $14,490,332$ & $13,808,301$ & $31,485,777$ & $6,212,293$ & $12,624,036$ \\
\hline May & $23,120,937$ & $18,530,706$ & $16,960,974$ & $37,858,654$ & $9,118,934$ & $16,352,435$ \\
\hline June & $27,059,769$ & $25,606,018$ & $23,606,926$ & $44,139,952$ & $11,920,934$ & $20,718,498$ \\
\hline July & $30,339,326$ & $28,075,063$ & $26,499,001$ & $49,757,516$ & $13,988,371$ & $22,969,400$ \\
\hline Aug & $33,967,639$ & $30,061,784$ & $29,459,611$ & $54,529,190$ & $16,232,557$ & $25,390,389$ \\
\hline Sep & $36,887,237$ & $33,954,873$ & $34,632,386$ & $60,171,770$ & $18,328,649$ & $27,046,432$ \\
\hline Oct & $41,254,254$ & $36,550,858$ & $37,463,787$ & $68,205,242$ & $21,026,506$ & $29,597,931$ \\
\hline Nov & $45,167,903$ & $40,370,288$ & $40,620,956$ & $73,456,962$ & $23,096,615$ & $31,553,171$ \\
\hline Dec & $48,564,557$ & $44,856,597$ & $43,827,045$ & $82,009,995$ & $25,638,925$ & $34,092,998$ \\
\hline
\end{tabular}

* Includes \$4,005,874 from the Democratic Congressional Campaign Committee-Contributions Source: Data compiled from Federal Election Commission electronic filings, http://www.fec.gov

In terms of individual "hard money" contributions to party committees in 1999, all three Republican committees raised more money from individuals than their Democratic counterparts. The hard money gap was less for the DSCC compared to the NRSC, but it was very large for both the DCCC and DNC. All party committees saw dramatic growth in individual contributions between 1999 and 2003. By 2007, the DSCC and DCCC raised more money from individuals than their equivalent GOP committees. A remarkable turnaround from 1999.

As noted, BCRA increased the maximum amount an individual could contribute to party committees. To what extent have party committees tapped into this source of funds? Have party committees seen the same surge in small, unitemized contributions in the last two presidential election cycles? To explore these questions we contrast in Table 5 the money raised from individuals giving 
the maximum permitted with the level of unitemized contributions in 2002, the last election conducted under the rules of the FECA, and in the 2004 and 2006 elections, the first elections held under BCRA. Table 5 looks at total 2-year cycle contributions, unlike Tables 1-4 which report data only on the year or years before the year of the election.

Looking only at total contributions from individuals, the Democratic National Committee made dramatic gains in 2004, to surpass the RNC in total contributions from individuals. The DNC raised just under $\$ 357$ million from individuals, compared to the RNC's $\$ 350$ million. The RNC did better among max-out donors than the DNC in 2004, but the DNC outperformed the RNC in unitemized donors, $\$ 166$ million compared to $\$ 157$ million. Contrary to the speculation of some prior to the implementation of BCRA, the soft money ban did not "short-circuit the efforts ... to revitalize political parties" (Milkis 43).

Looking at the same time period for the DSCC, the change is even more dramatic. In 2002 the DSCC raised only about half as much money from individuals as the NRSC did. In 2004 individual contributions to the DSCC climbed to near-parity with the NRSC, then far surpassed the NRSC in 2006. Max-out donors have been important to the DSCC over time and were a large part of the committee's success in 2004 and 2006. But the DSCC has also made major strides in small unitemized contributions. In 2007, the NRCC actually fell behind the DCCC in individual contributions, and early signs suggest that it will again surpass the NRCC in fundraising from individuals in 2008 (O'Connor 2008). Our studies of competitive contests for Congress in 2004 and 2006 also found substantial amounts of money being contributed by individuals to candidates in those races (see Magleby, Monson, and Patterson 2005, 36-41; Magleby and Patterson 2008, 24).

Table 5

\section{Sources of Receipts for National Party Committees, 2002-06}

\begin{tabular}{|c|c|c|c|c|c|c|}
\hline & \multicolumn{3}{|c|}{ DNC } & \multicolumn{3}{|c|}{ RNC } \\
\hline & 2002 & 2004 & 2006 & 2002 & 2004 & 2006 \\
\hline Total Receipts & $\$ 67,497,257$ & $\$ 394,411,997$ & $\$ 130,821,232$ & $\$ 170,099,094$ & $\$ 392,413,393$ & $\$ 243,007,131$ \\
\hline Total Contributions from Individuals & $\$ 55,623,021$ & $\$ 356,975,734$ & $\$ 117,948,743$ & $\$ 157,825,892$ & $\$ 350,368,907$ & $\$ 213,453,376$ \\
\hline Unitemized* & $\$ 37,820,051$ & $\$ 165,774,626$ & $\$ 73,197,298$ & $\$ 102,927,710$ & $\$ 157,091,853$ & $\$ 112,849,192$ \\
\hline Unitemized as \% of Total from Individuals & $67.99 \%$ & $46.44 \%$ & $62.06 \%$ & $65.22 \%$ & $44.84 \%$ & $52.87 \%$ \\
\hline Contributions at the Maximum Permitted ${ }^{* *}$ & $\$ 680,000$ & $\$ 43,350,000$ & $\$ 3,756,200$ & $\$ 2,980,000$ & $\$ 60,850,000$ & $\$ 801,000$ \\
\hline Maximum Donations as $\%$ of Individual Total & $1.22 \%$ & $12.14 \%$ & $2.87 \%$ & $1.89 \%$ & $17.37 \%$ & $0.38 \%$ \\
\hline Contributions from Federal Candidates & $\$ 55,113$ & $\$ 24,063,496$ & $\$ 1,099,873$ & $\$ 160,250$ & $\$ 26,678,514$ & $\$ 1,274,385$ \\
\hline Contributions from PACs & $\$ 1,099,514$ & $\$ 3,038,036$ & $\$ 1,490,203$ & $\$ 703,084$ & $\$ 2,970,840$ & $\$ 2,169,356$ \\
\hline Transfers from State or other National Parties & $\$ 6,560,050$ & $\$ 378,869$ & $\$ 466,738$ & $\$ 3,522,399$ & $\$ 4,655,873$ & $\$ 4,556,649$ \\
\hline
\end{tabular}




\begin{tabular}{|lllllll|}
\multicolumn{1}{l}{} & \multicolumn{1}{c}{ DSCC } & & & NRSC \\
\hline & $\mathbf{2 0 0 2}$ & $\mathbf{2 0 0 4}$ & $\mathbf{2 0 0 6}$ & $\mathbf{2 0 0 2}$ & $\mathbf{2 0 0 4}$ & $\mathbf{2 0 0 6}$ \\
\hline Total Receipts & $\$ 48,391,653$ & $\$ 88,655,573$ & $\$ 121,376,959$ & $\$ 59,161,387$ & $\$ 78,980,487$ & $\$ 88,812,386$ \\
\hline Total Contributions from Individuals & $\$ 20,168,297$ & $\$ 57,756,029$ & $\$ 87,232,426$ & $\$ 41,533,725$ & $\$ 60,811,444$ & $\$ 65,214,270$ \\
\hline Unitemized* & $\$ 9,723,282$ & $\$ 21,179,393$ & $\$ 24,506,860$ & $\$ 20,231,352$ & $\$ 29,998,982$ & $\$ 24,525,559$ \\
\hline Unitemized as \% of Total from Individuals & $48.21 \%$ & $36.67 \%$ & $28.09 \%$ & $48.71 \%$ & $49.33 \%$ & $37.61 \%$ \\
\hline Contributions at the Maximum Permitted** & $\$ 2,020,000$ & $\$ 12,175,000$ & $\$ 10,016,700$ & $\$ 320,000$ & $\$ 6,125,000$ & $\$ 2,132,600$ \\
\hline Maximum Donations as $\%$ of Individual Total & $10.02 \%$ & $21.08 \%$ & $11.48 \%$ & $0.77 \%$ & $10.07 \%$ & $3.27 \%$ \\
\hline Contributions from Federal Candidates & $\$ 1,820,984$ & $\$ 14,637,708$ & $\$ 11,817,188$ & $\$ 1,621,321$ & $\$ 3,846,670$ & $\$ 4,657,000$ \\
\hline Contributions from PACs & $\$ 4,707,156$ & $\$ 6,281,744$ & $\$ 7,911,614$ & $\$ 4,206,101$ & $\$ 7,714,233$ & $\$ 8,699,844$ \\
\hline Transfers from State or other National Parties & $\$ 7,100,082$ & $\$ 8,166$ & $\$ 1,066,159$ & $\$ 6,580,615$ & $\$ 501,961$ & $\$ 5,042,400$ \\
\hline
\end{tabular}

\begin{tabular}{|lllllll|}
\multicolumn{1}{c}{ DCCC } & & \multicolumn{2}{c}{ NRCC } \\
\hline & $\mathbf{2 0 0 2}$ & $\mathbf{2 0 0 4}$ & $\mathbf{2 0 0 6}$ & $\mathbf{2 0 0 2}$ & $\mathbf{2 0 0 4}$ & $\mathbf{2 0 0 6}$ \\
\hline Total Receipts & $\$ 46,436,093$ & $\$ 93,168,931$ & $\$ 139,891,645$ & $\$ 123,615,586$ & $\$ 185,719,489$ & $\$ 179,549,131$ \\
\hline Total Contributions from Individuals & $\$ 19,393,788$ & $\$ 50,690,882$ & $\$ 83,158,357$ & $\$ 79,175,374$ & $\$ 145,858,047$ & $\$ 112,066,248$ \\
\hline Unitemized* & $\$ 11,201,482$ & $\$ 25,141,719$ & $\$ 32,013,707$ & $\$ 39,673,242$ & $\$ 49,789,260$ & $\$ 42,369,374$ \\
\hline Unitemized as \% of Total from Individuals & $57.76 \%$ & $49.60 \%$ & $38.50 \%$ & $50.11 \%$ & $34.14 \%$ & $37.81 \%$ \\
\hline Contributions at the Maximum Permitted** & $\$ 800,000$ & $\$ 6,675,000$ & $\$ 5,265,950$ & $\$ 180,000$ & $\$ 3,775,000$ & $\$ 186,900$ \\
\hline Maximum Donations as \% of Individual Total & $4.13 \%$ & $13.17 \%$ & $6.33 \%$ & $0.23 \%$ & $2.59 \%$ & $0.17 \%$ \\
\hline Contributions from Federal Candidates & $\$ 12,131,368$ & $\$ 23,958,309$ & $\$ 33,355,498$ & $\$ 14,077,114$ & $\$ 24,247,276$ & $\$ 30,223,581$ \\
\hline Contributions from PACs & $\$ 4,157,049$ & $\$ 6,447,173$ & $\$ 7,284,668$ & $\$ 4,661,590$ & $\$ 8,595,727$ & $\$ 11,199,585$ \\
\hline Transfers from State or other National Parties & $\$ 3,207,213$ & $\$ 652,638$ & $\$ 954,500$ & $\$ 4,454,900$ & $\$ 1,204,620$ & $\$ 18,117,022$ \\
\hline
\end{tabular}

Source: Federal Election Commission, "Party Financial Activity Summarized for the 2006 Election Cycle," press release, March 7, 2007. At <http://www.fec.gov/press/press2007/partyfinal2006/20070307party.shtml>, accessed June 4, 2007.

Note: This table includes federal or "hard" money only.

*Unitemized contributions from individuals are those which aggregate \$200 or less in a calendar year from a single person.

**The maximum contribution from individuals was changed from $\$ 20,000$ per year to $\$ 25,000$ per year for the 2004 election cycle and \$26,700 per year for 2006.

\section{CONCLUSION}

The dramatic growth in the numbers of individuals contributing to presidential candidates and the surge in total amounts being contributed has generated substantial media attention in the 2008 presidential election. What is less well understood is that individuals are giving more, in part, because the limits were raised by BCRA. More research needs to be done on what is motivating more 
people to give in 2008, but clearly there is a higher level of interest in this election, at least as measured by campaign contributions.

But the increase in political giving by individuals is not limited to presidential candidates. It is part of a broader pattern that started in the 2004 election cycle and continued in 2006. Part of the increase may be driven by the ease of contributing via the Internet, part of it may be due to passion about the wars in Iraq and Afghanistan, and some of it may be due to enthusiasm for the candidates. Whatever the motivation, increased giving is not isolated to the 2008 presidential contest and therefore may have long-lasting significance.

\section{REFERENCES}

Campaign Finance Institute. 2008. Presidential fundraising in 2007 doubles 2003. Press release, February 11. http://www.cfinst.org/pr/prRelease.aspx?ReleaseID=179.

Center for Responsive Politics. 2007. Federal campaign finance law: Contribution limits. OpenSecrets.org. http://www.opensecrets.org/basics/law/index.asp.

Davies, Frank. 2008. Obama capturing new voters, funds through Internet. San Jose Mercury News. February 24.

Frontrunner. 2007. Edwards campaign profits from Coulter's "hurtful" attacks. June 28.

Gitell, Seth. 2003. The Democratic Party suicide bill. Atlantic Monthly 292, no. 1 (July/August), 106-113.

Goff, Michael J. 2004. The money primary. Lanham, MD: Rowman and Littlefield.

Green, John C. 2006. Financing the 2004 presidential nomination campaigns. In Financing the 2004 election, ed. David B. Magleby, Anthony Corrado, and Kelly D. Patterson, 93-125. Washington, DC: Brookings Institution Press.

and Nathan S. Bigelow. 2002. The 2000 presidential nominations: The costs of innovation. In Financing the 2000 election, ed. David B. Magleby, 49-78. Washington, DC: Brookings Institution Press. 
Horowitz, Jason. 2008. Obama bundlers rejoice in their decreasing relevance. New York Observer. February 6.

Kolodny, Robin, and Diana Dwyre. 2006. A new rule book: Party money after BCRA. In Financing the 2004 election, ed. David B. Magleby, Anthony Corrado, and Kelly D. Patterson, 183-207. Washington, DC: Brookings Institution Press.

Krasno, Jonathan, and Frank Sorauf. 2003. Why soft money has not strengthened parties. In Inside the campaign finance battle: Court testimony on the new reforms, ed. Anthony Corrado, Thomas E. Mann, and Trevor Potter, 4968. Washington, DC: Brookings Institution Press.

Luo, Michael. 2008. Small online contributions add up to huge fund-raising edge for Obama. New York Times. February 20. and Jeff Zelleny. 2008. Obama and Clinton flush with cash from February. New York Times. February 29.

Magleby, David B., and William G. Mayer. 2008. Presidential nomination finance in the post-BCRA era. In The making of the presidential candidates 2008, ed. William G. Mayer, 141-168. Lanham, MD: Rowman and Littlefield.

and J. Quin Monson. 2004. The consequences of noncandidate spending, with a look to the future. In The last hurrah? Soft money and issue advocacy in the 2002 congressional elections, ed. David B. Magleby and J. Quin Monson, 259-280. Washington, DC: Brookings Institution Press.

_, J. Quin Monson, and Kelly D. Patterson. 2005. The junior prom: The dynamics of the 2004 congressional campaigns. In Dancing without partners: How candidates, parties, and interest groups interact in the new campaign finance environment (monograph), ed. David B. Magleby, J. Quin Monson, and Kelly D. Patterson, 36-41. Provo, UT: Center for the Study of Elections and Democracy, funded by the Pew Charitable Trusts.

and Kelly D. Patterson. 2008. Rules of engagement: BCRA and unanswered questions. In The battle for Congress: Iraq, scandal, and campaign finance in the 2006 election, ed. David B. Magleby and Kelly D. Patterson, 22-61. Boulder, CO: Paradigm Publishers. 
Milkis, Sidney M. 2003. Parties versus interest groups. In Inside the campaign finance battle: Court testimony on the new reforms, ed. Anthony Corrado, Thomas E. Mann, and Trevor Potter, 40-49. Washington, DC: Brookings Institution Press.

O'Connor, Patrick. 2008. Boehner tells GOP to get off "dead asses." Politico. February 27. http://www.politico.com/news/stories/0208/8713.html.

Patterson, Kelly D. 2006. Spending in the 2004 election. In Financing the 2004 election, ed. David B. Magleby, Anthony Corrado, and Kelly D. Patterson, 68-92. Washington, DC: Brookings Institution Press.

Weissman, Steve, and Taylor Lincoln. 2007. Fundraising central: Majority of presidential bundlers and other fundraisers hail from only five U.S. industries. Campaign Finance Institute and Public Citizen. December 20. http://www.citizen.org/documents/IndustryCoding.pdf. 